\title{
The mass: A neglected plastic sign of sculpture
}

\section{Sergei Kruk}

By and large visual semiotics still misses a comprehensive method for the analysis of sculpture. The paper demonstrates that sculptures have a peculiar plastic sign - the mass. Intrinsic to three-dimensional objects, the mass determines the forces of gravity and inertia possessing a potential to suggest connotations of the artwork. Taking as examples the large monuments built in Soviet Latvia in 1960-1990, the paper distinguishes among three categories of monuments - static, dynamic and ambiguous - which owe their particular characteristics to diverse exposure of the mass enabled by various constructive techniques. As iconic signs these monuments represent actual identities and events while the exposed mass, as a plastic sign, conveys additional connotations like stability, change, motion, standstill, slowness, speed enabling a more nuanced interpretation of the represented persons and events. As a physical property of objects mass can be evaluated by handling them directly but the public is supposed to look at sculpture not to touch and handle it. The current psychology of perception holds however that the perceiver goes beyond the information given in the visual input, the process of perception depends also on the perceiver's knowledge and purposes in the contact with reality. Ubiquity of outdoor sculpture suggests that our accumulated experience of 3D artistic objects can be embedded into the elaboration of the visual input thus the viewers can perceive the mass and enrich the interpretation of sculpture considering the meanings of this plastic sign.

Keywords

Sculpture, Three-dimensional Objects, Tectonics, Plastic Sign, Mass, Visual Semiotics, Soviet Latvia

\section{Semiotics of three-dimensional artwork}

More than a century ago sculptor and pioneer of the formal analysis of visual art Adolf Hildebrand ([1893]1914: 68-69) wrote that sculpture originated from drawing as it was turned into relief. Sculptors start carving the stone keeping in mind only one view from one particular 
position. Drawing a picture on the main surface of stone sculptor respects the formal rules of the figurative activity of a painter. Accordingly, viewers are expected to perceive sculptures just like flat pictures.

Suffice to glance over the content pages of some contemporary books on visual semiotics and semiotics of art to find out that sculpture is not treated as a kind of visual representation sui generis: it is relegated to flat pictures or neglected altogether (e.g. Calabrese 2006; Eugeni 2004; Lancioni 2012; Nöth 1990; Volli 2008). The real 3D characteristics are being studied as visual effects on 2D pictures: impression of weight on flat images (Arnheim 1974), illusion of texture created by lines, dots and hatching on smooth surface (Danesi 2004: 75-80; Eugeni 2004). These authors do not notice that sculpture is a corporeal phenomenon: sculptors assemble their artwork from objects possessing mass. Mass is a measure of amount of matter in an object described by the formula $m=V \rho$ where $V$ stands for the volume and $\rho$ for the density of material. Mass also is the measure of gravity and inertia or resistance to acceleration. The more is the object's mass, more force is required to change its state (Deeson 2007: 270; Prokhorov 1998: 392). Physical characteristics related to the mass determine a variety of the object's qualities and states: motion versus standstill, fast versus slow, change versus stability. Manipulating with the load and support distribution the sculptor can visualize these abstract notions thus investing the artwork with a surplus meaning which cannot be derived from the iconic representation of a person or an event the sculpture is dedicated to.

British art critic Herbert Read (1956) explained that the neglect of corporeality was due to a particular historical function of sculpture which was subordinated to the architecture during the millennia. Placement in the front of a building prevented viewers from observing statues from different visual angles and consequently the artists developed a painterly conception of sculpture. They were concerned with the coherence of surfaces rather than with the realization of mass. The Renaissance released statue from the building however the free-standing sculpture in the round failed to find its proper place in the arts because a new aesthetics lagged behind still. Triumph of the painterly conception doomed the art of sculpture to a progressive degeneration until the end of the $19^{\text {th }}$ century and Hildebrand's concept belongs to this trend. The concept privileged visual sensibility whereas sculpture engenders tactile sensations also, Read contends. He does not mention Johan Gottfried Herder's name who expressed the same idea almost two hundred years earlier. In an essay Sculpture ([1778]2005) the German philosopher sought to rehabilitate the special status of sculpture as a 3D object. Sight and hearing were two privileged senses classifying the fine arts, explained Herder. But 3D objects are physically present, they are tangible and therefore can be touched. Herder anticipated the ecological theory of vision (discussed in section 5) contending that the viewer actively explores the surrounding objects over time. '[A sculpture] presents a human being, a fully animated body, it speaks to us as an act; it seizes hold of us and penetrates our very being, awakening the full range of responsive human feeling' (Herder [1778]2005: 80). 
Herder's idea was reanimated by Russian art historian Alexander Gabrichevsky (1923). He reminded that the discipline of aesthetics had borrowed most of notions from the visual perception whereas plastic art evokes tactile sensations first of all. Sculpture cannot be reduced to flat images because it possesses the mass which is a resource of connotations. Namely, plastic artwork creates an impression of perpetuation because its physical qualities are opposed to temporal fluctuations and mutability. Besides, 3D objects have an anthropomorphic organization, i.e. they are commensurable to humans. For example, more massive constructions are perceived as abstract and symbolic.

Making a stand against Hildebrand, Susanne Langer (1953) reminded about the voluminosity of sculpture. She treated this artwork as shapes placed in a real space creating a virtual space; however, these are empty shapes. Stating that sculpture realizes 'an integral mass into actual space' (1956: 71) Read filled them with material. As a physical object sculpture possesses characteristics absent in painting: volume, weight, mass and occupation of space. Unlike canvas, touching and handling objects provides more information about their qualities. Viewers need a plastic sensibility to these characteristics: a sensation of tactile quality of surfaces; a sensation of volume as denoted by plane surface; and a synthetic realization of the mass and ponderability of the object. Read does not propose details about the visual perception of the mass and its connotations. Sometimes he confuses mass with the material and reduces its perception to tactility, palpability. He argues, for example, that tactile values can be 'conveyed directly, as existent mass' and all the art of sculpture becomes 'an art of palpation' (Read 1956: 49). He agrees that mass of the small objects can be estimated by handling them, as to the large-scale sculpture it 'is felt by the sculptor toward his carving whatever its size' (Read 1956: 74).

Denis Alcan (1981) exposed a specific meaning of material and mass in Constantin Brancusi's plastic artwork. Brancusi drew attention to the difference between everyday objects and sculpture. The artwork resembles the object by the similarity of volumes, but it is the sculpture's mass which negates the meaning suggested by the visual similitude. Alcan described one series of sculptures, but he has not formalized a method of analysis.

The notion of plastic sign invented by Groupe $\mu$ (1979) and later developed by Algirdas Julien Greimas (1989) opened a new perspective for the semiotic analysis of sculpture. Visual artwork refers the viewer to somebody or something by virtue of the iconic likeness to the referent. Greimas argues that iconic signs are composed of minimal units which themselves can evoke meaning related to their materiality. For example, colors evoke concepts of warmth or coldness; curvilinear and rectangular forms hint to femininity or masculinity. The interest to these minimal units called by Greimas 'plastic figures' (or plastic signs) was raised by the abstract painting devoid of iconic likeness: here plastic signs qualify as the only carriers of eventual meaning. Jean-Marie Klinkenberg (1996: 378-382) distinguishes between iconic signs which point to something by virtue of mimetic likeness and plastic signs which mobilize the codes independently of mimetic pointing to something. He mentions three plastic signs: form, colors and texture. Plastic form is 
a spatial form which is subdivided to smaller formemes possessing their own potential meaning: position, dimension and orientation. Colors as well have smaller unities called chromemes: chromatic dominance (a certain wave length which we label usually by words red, green, etc.), saturation (proportion of two types of light: white light and one corresponding to the given chromatic dominant) and luminance (quantity of the luminous energy). Finally, texture is related to quality of a surface: smooth, granular, etc. Unevenness of surface as a textural characteristic could qualify as a 3D phenomenon. However, Groupe $\mu$ (1992) argues that it is applicable only to planar images while three-dimensionality is a characteristic of the material support of pictures. Granular surfaces determine effluence of paint spots; painters consider the texture when they select paper expecting to obtain certain effects.

Greimas, Klinkenberg and Groupe $\mu$ reduced the study of plastic signs to planar representations. Just like Hildebrand they do not notice at least one important characteristic which sets sculpture apart from pictures: the minimal units in sculptor's disposal are the solid bodies, casings and grid-shells whose intrinsic property is the mass which can carry meanings related to the phenomena of gravity and inertia. As a semiotic phenomenon mass is treated explicitly by Michael O'Toole (1994: 32-84) who took over all the qualities of sculpture mentioned by Read attempting to conceptualize them theoretically. Alas, with no success. Five qualities are grouped under a category mass as a system: 1) center of gravity; 2) solidity / penetrability; 3) interplay with space; 4) line / relief; 5) plasticity. Despite the title only the first quality has a relation to the mass - it will be discussed extensively in this article later. Qualities 2 and 5 describe the properties of solid bodies as such rather than their mass: resistance to a more solid body and strength under load. Quality 3 is treated in terms of volumes; it is not specified whether and how the material filling is implied in this interplay. Quality 4 is related to the object's contour and surface; the author's explanation of its physical relation to the mass is untenable: 'A stress on relief and plasticity in the surface [...] draws attention to the mass more than to its linear qualities' (O'Toole 1994: 34). In no wise 'draws attention' explains how the mass is estimated by viewers and what effect the estimation has on interpretation.

Another problematic category is equilibrium as a system encompassing two qualities: 1) verticality (vertical, steep angle, shallow angle, horizontal) and 2) chtonicity (merged with the earth, earth bound, thrusting, airborne). Actually, equilibrium is the state of all sculptures otherwise they would fall down. What makes the plastic artwork to stay firmly on the ground is the correctly calculated center of gravity. Being the function of mass, it fits the category mass as a system better. An image of disequilibrium can be created for the artistic purposes by distributing masses in an unusual manner and holding the whole artwork together by special constructive structures.

Inadequacy of the concept of mass becomes evident when after the theoretical introduction O'Toole goes ahead with the analysis of monuments. He dispenses with the mass altogether treating three-dimensionality in Langer's way as a spatial property only: proportion 
of the parts, placement in the urban space and relations with the viewer. In the 30-pages long analysis of four sculptures the term mass appears only once in a quotation.

Gunther Kress and Theo van Leeuwen (2006) dedicated a special chapter (titled: The third dimension) to sculpture and toys. The specific properties of these objects are material, surface, overall shape and composition; the mass is not mentioned at all. The main difference from pictures is that sculptures can be intended for observation either from only one side or from many sides because the viewer can move around. Surface and material engage tactile perception which helps the viewer to make sense of physical objects. Objects are not only looked at but also used. Nevertheless, art objects exposed indoors are not allowed to be approached and touched; for this reason, the viewer cannot see them from all possible angles and interact physically.

Robert Vance (1995) contends that a visual image owes to a combined work of different senses, but he explains nothing about the physical characteristics of sculpted objects which convey these senses in action. Observation of a sculpture evokes tactile, haptic and kinesthetic imaginings which involve somatic sensations; exercise of the latter engenders identifications with the sculpture so far that it is felt as an extension of the viewer's own body. In the final account, the feelings determine the visual features, i.e. what the viewer actually sees. 'The sculpture will look dynamic, threatening, or inscrutable, because it feels dynamic, threatening, or inscrutable' (Vance 1995: 225). Vance's feelings and imaginings are dispossessed of visible physical stimuli therefore the question remains open: why it feels like this?

Some more scholars expressed the urgent need to respect the phenomena of corporeality and mass, but they did not offer theoretical models and methods (e.g. Rogers 1962; Martin 1978; Serres [1987]2014: 89-111; Marsciani 1999; Koed 2005; Chateau 2010; Klinkenberg 2010; Savage 2010). Even a collection of articles under an intriguing title La sémiotique visuelle: nouveaux paradigmes (Costantini 2010) did not propose a new approach to 3D objects. The Soviet scholars on their part did respect the mass writing about large scale monuments but their problem was a lack of analytical precision. The notion of tectonics borrowed from the vocabulary of architects permitted to connect mass to meaning, but unfortunately the scholars failed to formalize the method of interpretation using the term as a metaphor. This is why we need to shift to architecture in the next section.

\section{Tectonics of buildings}

The term tectonics has a long history in German and Russian literature on architecture. It differentiates between the material and aesthetic aspects of construction industry. Karl Bötticher (1852: 1) has defined tectonics as 'the building and furnishing activity'. The construction activity depends not merely on physical requirements advanced to buildings but on beauty as well. To distinguish between two phenomena, Bötticher proposed the notions of core-form 
(Kernform) and art-form (Kunstform) (1852: 21-26; see in Mallgrave 2006: 532). Core-form are the mechanical qualities of construction which keep it safe and stable while art-form expresses the mechanical functions of constructive parts. Bötticher favored those art-forms which articulated the physical laws intrinsic to core-form. Gottfried Semper ([1851]1989) in The Four Elements of Architecture regarded symbolic expressions as autonomous rather than dependent on constructive parts. In Wissenschaft, Industrie und Kunst, published one year later, he wrote about intrinsic and extrinsic variables. The former are the materials and technical means of production, the latter are the local, temporal, national and personal factors affecting the work.

Moisei Ginzburg (1927: 164) introduced the notion of tectonics in Russian discussing the constructivist architectural style. Tectonics refers to technical aspects of buildings such as articulation and proportion of parts of the whole. Subsequently other Russian authors added aesthetic aspects of constructions to their definitions of tectonics but still today there is no agreement on the proper use of the term. The various definitions connote one of these three features of the design:

Constructive: rules of combination of parts permitting the stability of construction. Definitions highlighting this feature account for the technical aspects of constructions: relations between bearing and load, static strains.

Expressive: visual exposure of the intrinsic qualities of constructive structures; the structure exists by virtue of relations of the real forces thus the structure might function as an ostensive sign of its own tectonics. Definitions respecting this feature refer to an image of forces keeping the whole building.

Artistic: application of extrinsic artistic means to express the intrinsic qualities of constructive structures. Definitions stressing this feature hold that tectonics is an artistic tool evoking connotations.

Like Bötticher, the Soviet authors that adhered to rationalist architecture subordinated aesthetics to mechanics. Since safety of constructions and conveniences is valued above all, the building's visual appearance must represent the static strains truthfully in order to assure customers that it will not collapse. In the 1930s, authors greeted the return back to the principles of classicism because the clear mass of constructive bodies, delimited space, order composition and harmonious proportion of forms constituted the ideal of architecture (Lunacharsky 1934; Nekrasov 1934). Alexey Nekrasov ([1945-1946] 1994) defined tectonics as an image of a construction, i.e. an image of mass organized in order to preserve statics, balance and thereby the forces of gravitation, weight and stress intrinsic to the construction. Nekrasov treated the Rococo style with contempt exactly because its excessive decorations concealed 
the constructive elements ensuring the building's stability. Similar definitions of tectonics were given by other Soviet sources: artistic expression of structural patterns intrinsic to constructive system of building (Bolshaia, vol. 2, 1970); an expression of material and technical structure by aesthetic means and plastic expression of physical qualities of material (Tits 1976: 93). The most recent literature mentions similar arguments: architectural decorations should be used to imitate the structure's real forces, underline visual safety of constructions, stability of bearing and load proportion, strength of frame units, ponderability of bases (Artiukhovich 2011: 639; Batorevich and Kozhitseva 2001: 300; Ikonnikov 1986: 61; Ivanova and Stepanov 2007: 37; Pluzhnikov 2011: 26; Vlasov 2004: 160; Yusupov 1994: 352).

Gottfried Semper's book was published in Russian translation in 1970 but his idea of autonomous artistic expression got no acceptance among Russian authors. Alexey Tits and Elena Vorobyova (1986: 47-48) recognized what they called 'false tectonics' or 'atectonics'. They contend that for the artistic purposes the decorative forms may misrepresent the bearing capacity and the stress of construction elements. Still some authors characterize it as unnatural, inharmonious and sham (Sotnikov 2009: 54). Art historian Grigory Revzin (2002: 85-108) pointed that the disdain for atectonics prevented the Russian scholars from understanding the $19^{\text {th }}$ century eclecticism. This style takes on special significance when one sees the façade as an expression of incorporeal surface on which decorations are hanging and gliding in the air.

Another ambiguous term is architectonics; its relation to tectonics is stated in three different ways:

Architectonics is a synonym of tectonics (Bolshaia vol. 2, 1970; dictionaries of Russian language).

Tectonics connotes the structure or intrinsic constructive qualities; and architectonics connotes the surface or extrinsic artistic exposure (dictionaries of architecture; Vlasov 2004).

Architectonics is a general term encompassing the principles of composition in arts; tectonics is a particular term referring to 3D objects (dictionaries of culture).

There are historical reasons explaining and justifying the use of building vocabulary in plastic art. Making a bid for the state and municipal contracts the scholars of arts discussed sculpture in close coordination with the new architectural design of the modern industrial urban environment. Consequently, the sculpture's dimensions increased in proportion to the surrounding buildings and sculptors needed an adequate language to talk about these monumental structures. Next section traces back the gigantism turn of the outdoor sculpture in the Soviet Union. 


\section{Soviet sculpture becomes massive}

The idea of political communication by means of sculpture - monumentalnaya propaganda - advanced by the Bolshevik government in 1918 provided the political rationale to artistic endeavors. The Russian adjective monumentalnaya signifies that the political communication is being accomplished by means of commemorative signs. In the given economic conditions, the government had no intention to carve huge 'monumental' sculptures. Among the first monuments there were many small busts cast in non-permanent materials - plaster and concrete. In 1925, a government commission supervising the production of outdoor sculptures pinpointed about monumentalnost': 'a part of an architectural composition inextricably connected to its environment and having the nature of a permanent structure (e.g., monuments, busts, bas-reliefs)'1. The turn to gigantism occurred in the early 1930s and it is related to the tender for a monument to Columbus in Santo Domingo. Soviet constructivists designed several projects for the competition but all of them were rejected by the jury on the ground of missed monumentality, static and sublime character (Kazus' 2010). Specifications of the ensuing tenders in the Soviet Union reveal that the managers of architecture took in account the international critique. A tender for Lenin monument atop the beacon in the Leningrad seaport specified that the 120-meters-high construction had to become the highest monument in the world (Pravda 8 December 1931). In February 1932 the Government committee supervising the project of the Palace of Soviets in Moscow demanded the monumentalnost' of architectural forms (Soviet 1932). The monumentalnost' turn can be explained as a response to what was perceived as a new trend in the international outdoor sculpture set by the Columbus monument competition jury but there was also a local pragmatically dictated necessity. Having realized the lack of capacity to provide comfortable housing for all, the government opted for designing ostentatious ceremonial ensembles (Khan-Magomedov 2001). Industrial structures and urban planning provided for spacious areas which required large sculptural decorations to complete a good composition. Convergence of architecture and sculpture was imminent in 1930s (Azizyan 2010). In 1937 the sculptor Sergei Merkurov used huge concrete blocks to erect the first gigantic statues of Lenin and Stalin at the entrance of the Moscow Canal, at Dubna near Moscow (Figure 1). In the same year a factory Monumentskulptura was founded in Leningrad to cast a politically important 7.8-meters-high bronze sculpture of Sergei Kirov, the very recently killed mayor of the city. By this time the maximal size of sculptures produced at the industrial facilities could not exceed 6.5 meters. Soon after the inauguration, the industrial plant manufactured four monuments 7.2-9-meters-high. ${ }^{2}$ 


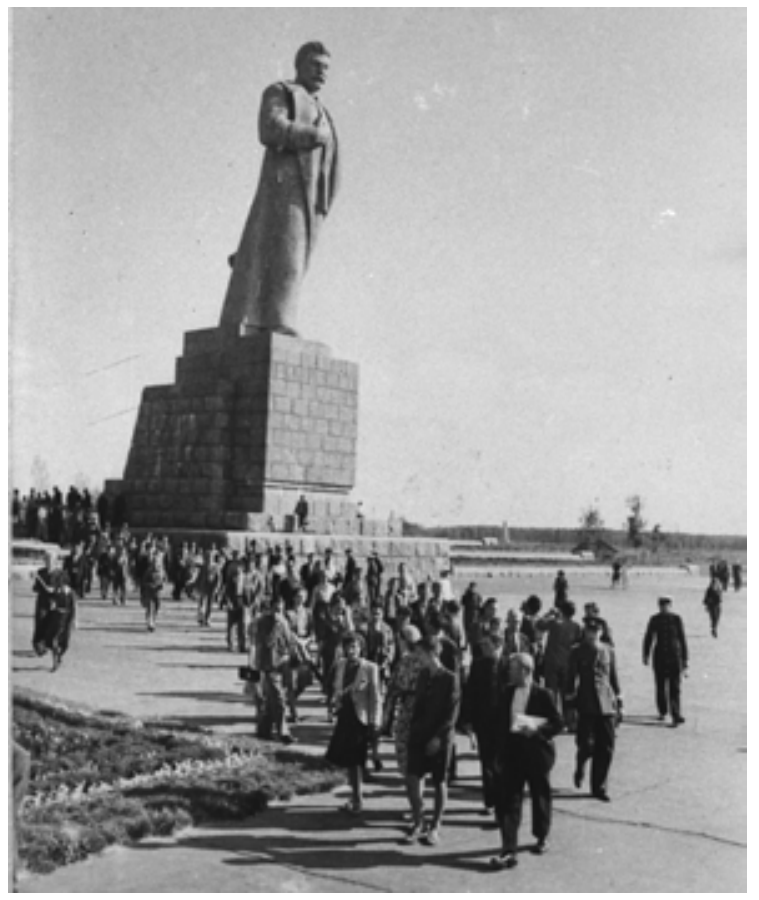

Figure 1: S. Merkurov. Stalin monument in Dubna. 1937-1961. Concrete, $h=37 \mathrm{~m}$. Courtesy of the National Archives of Estonia.

An unpublished dictionary of notions of arts drafted by the arts scholars in late 1920s inaugurated the treatment of monumentalnost' in terms of physical dimensions: 'mostly it is related to emphasizing the mass' (Chubarov 2005: 285). From 1950s the trend to gigantism is respected in the Russian language dictionaries and encyclopedias. The Russian has two words to designate outdoor sculpture. What the Oxford Dictionary defines as 'a statue, building, or other structure erected to commemorate a notable person or event' is pamiatnik (pamiat' - memory). Another Russian word monument designates a large commemorative structure. The noun has absorbed also the connotations of English adjective monumental - 'great in importance, extent, or size'. The first edition of the Great Soviet Encyclopedia made no such a distinction still. There is no an entry monument, while the entry monumentalnost' disclaims the importance of dimensions: 'Almost usually the bourgeois art historians treat monumentalnost' from the quantitative point of view (dimensions of monument), which is absolutely wrong' (Bolshaia 1938, vol. 40: 156). The second edition recognized the new trend in the definition of the word monument: 'usually monuments are of large-scale and mighty, monumental forms' (Bolshaia 1954, vol. 28: 262). The third edition defined monument as 'a pamiatnik of a considerable magnitude in honor of a great historical event, great public personality etc. Often monument is a conceptual and spatial-extensional dominant of architectural ensemble' (Bolshaia 1974, vol. 16: 550). Sculpture in the round was included among the objects of architectonics / tectonics (Bolshaia 1970, vol. 2: 296). 


\section{Latvians develop a new plastic language}

Despite the new role assigned to sculpture in the architectural environment of industrial towns, a new plastic language of monumentalnost' was developing slowly. Among the reasons was the absence of appropriate workshops and disregard of peculiar properties of large-scale sculpture by customers and artists who used simply to scale up an easel work to the given proportions of urban space 3 . An idiosyncratic plastic language of monumentalnost' was pioneered by Latvian sculptors. The founder of the Latvian school of sculpture, Teodors Zal,kalns (1876-1972), drew inspiration from the huge monuments of Ancient Egypt. The Soviet government made possible the realization of his artistic ambitions in practice: the new urban design fostered production of large artwork while the function of political communication assigned to outdoor sculpture facilitated access to large financial resources. From mid-1960s to 1990 successfully Latvian sculptors and architects lobbied for state and municipal budgets (Kruk 2010) and accumulated a great technical and artistic experience of assembling large monuments from heavy solid bodies ${ }^{4}$. Browsing 10,000 photos of Lenin monuments collected by Dmitry Kudinov at leninstatues.ru one can easily find out that Latvian sculptures were the most interesting; their grandeur evokes more connotations because of the effective use of the mass as a plastic sign.

Technically, mass sets the limits on spatial manipulations with the building blocks of monuments, i.e. on the load and support proportions. To assemble an artwork from heavy pieces of metal and stone the sculptor must consider the mechanic forces keeping the parts together. Latvian artists applied various engineering solutions enabling creative manipulation with load and support so that the unorthodox distribution of masses evoked more connotations besides ones triggered by the iconic images. Scholars of architecture and design disapproved a sophisticated distribution of masses concealing the secure constructive structures: seemingly violating the gravity law it makes constructions to look unsafe. Impression of safety is less important for the artwork because viewers are not obliged to 'risk their life' approaching and touching the object. However, designers use to play with atectonic unsafety for the emotional purposes. For example, to access the exposition of the memorial to Nazi victims in Salaspils one has to walk upstairs by the unstable knocking cement footsteps. Kinetic and auditory experience causes a visceral response when entering the place of suffering.

Atectonic structures prompt viewers to restore the impression of physical balance by reinterpreting the visually perceived mechanical strains created by the seemingly unbalanced distribution of masses. Pointing at the mass the sculptor evokes connotations related to gravity and momentum forces: motion versus stasis, fast versus slow, change versus stability. Mass as a plastic sign makes possible an analytical delimitation of three currents of the Soviet sculpture which mobilize meanings specific to static, dynamic and ambiguous solid bodies.

Static sculptures are tectonic objects: exposure of constructive structure reveals safety 
of the installations. Stone monuments are realized as monoliths or assembled from granite blocks; bronze sculptures are screwed from constitutive elements avoiding jutting parts that would have displaced the center of mass. Sculptures stand firmly on a plinth or a larger pedestal. Mechanical strains between load and support connote stability, constancy, authority, power, certitude. In the political context of Leonid Brezhnev's Soviet Union of the 1970s, later dubbed stagnation, these connotations conformed to the dominant discourse of the victory of socialism and stability. An art critique explained the connotations of Lenin monuments carved by Juris Mauriṇš (Figure 2).

Mauriņš does not represent a concrete documented event in the image, he does not strive for a nuanced psychological characterisation. Rather he tries to express the essence by the very sculptural masses. In town of Balvi the Lenin monument personifies the orator's persuasive force. A monolith, dynamic granite figure is arising from the tribune in a rapid motion... Tectonic expression has been magnified by the silhouette, figure's dynamics, and sharp linear rhythms of sculptural masses. This reinforces the symbolic meaning of the image. (Cielava 1980: 56)

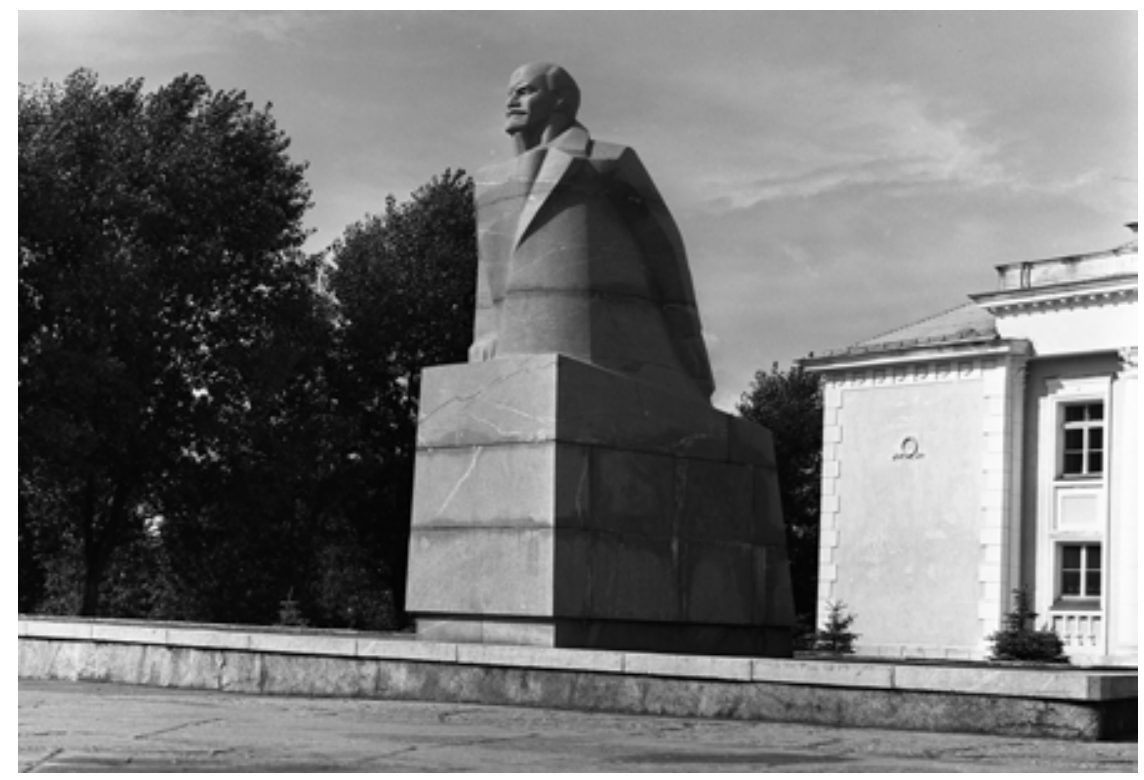

Figure 2: J. Maurinšs. Lenin monument in Balvi. 1973-1991. Granite, h=6 m. Courtesy of the National Administration of Cultural Heritage.

Lenin's monument in the central square in Alūksne (Figure 3) suggests that it is not the body's volume that makes the space proportional. The 3.5-meters-high red granite bust was put on a granite plates coated pedestal of approximately the same height but more than twice wider than the sculpture. By virtue of its mass - the bust's weight is 55 metric tons - the monument is a centripetal focus of a large square organizing gravity and balance of masses 
of surrounding buildings. A light conventional portrait stature could have not provided for a similar sense of proportion.

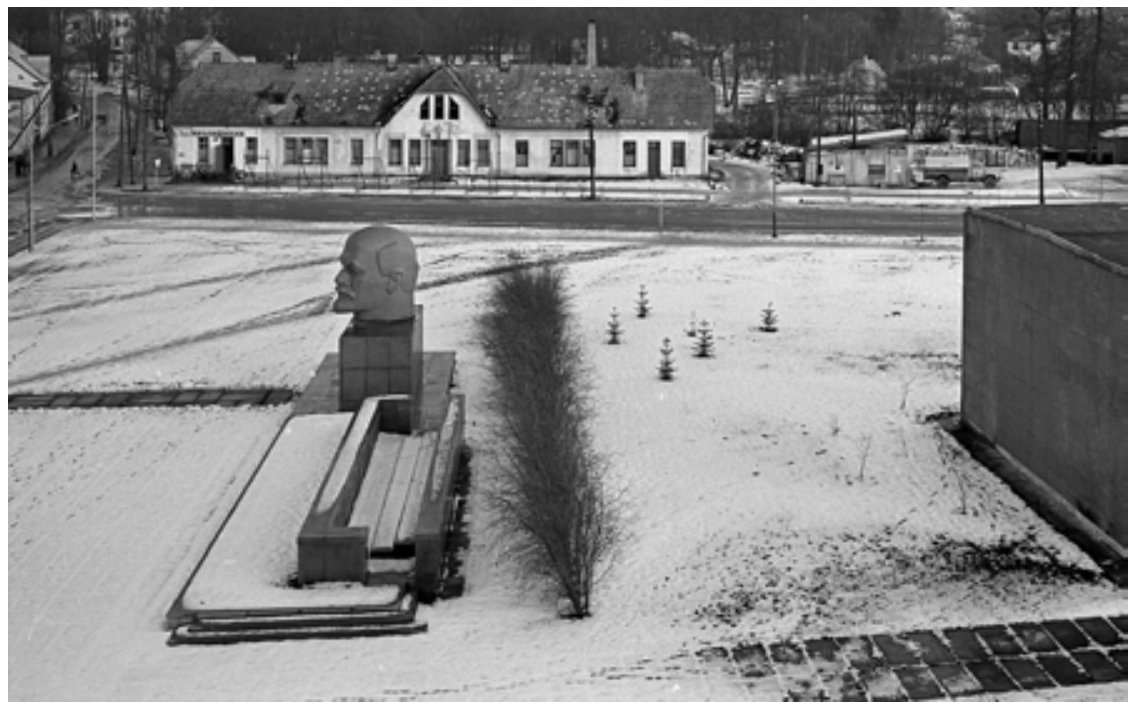

Figure 3: G. Grundberga. Lenin monument in Alūskne. 1970-1991. Granite, $h=3.5 \mathrm{~m}$. Courtesy of the National Administration of Cultural Heritage.

The 7-meters-high red granite monument to Red Latvian Riflemen, unveiled in Riga in 1971, represents three men on guard (Figure 4). The sculpture dominates the central square in the old town destroyed during the war and reconstructed to accommodate the monument. Actually, the square was redesigned as a gravitational interaction of masses. Perpendicular building of a museum cuts the large area in two and the monument organizes the space between the building and the river. In post-Soviet years the important political symbol was degraded by making its mass at odds with the general arrangement of the square. A kiosk and tourist bus parking place arranged nearby displaced the center of gravity so far that the robust piece of granite became a foreign body here.

Gravitational function was accorded to a static standing figure of the Soviet Latvia government leader, Pēteris Stučka, unveiled in Aizkraukle in 1978 (Figure 5). The town was founded just two decades earlier as a dwelling space for the employees of a hydro-electric power station inaugurated in 1965. Built-up area consists of many standard four-story houses with monotonous brick facades; buildings are distributed symmetrically leaving a large free space for public manifestations. Star architecture places the bronze statue in the geometrical center of dynamic forces and its mass connotes the gravitational center. Sculpture is comparable to houses in height but its compact volume, the material and evenly spaced location creates an impression of balancing the entire urban composition which otherwise misses some historically developed and semantically anchored attraction points. 


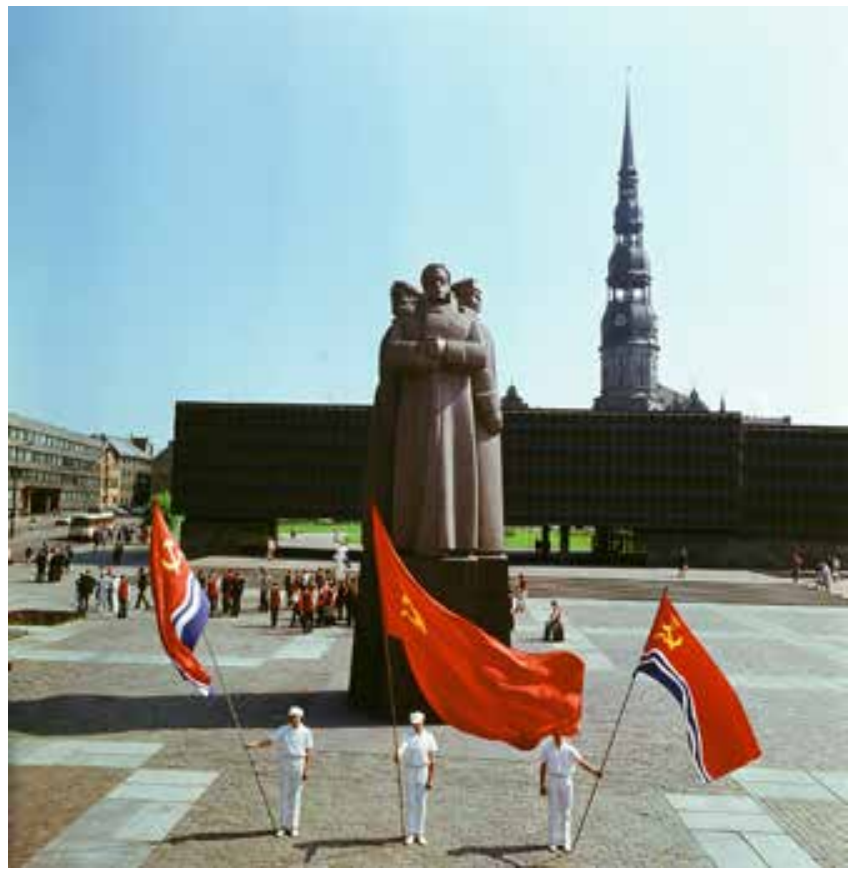

Figure 4: V. Albergs. Monument to the Red Latvian Riflemen in Riga. 1971. Granite, h=7 m (figure). Courtesy of the National Administration of Cultural Heritage.

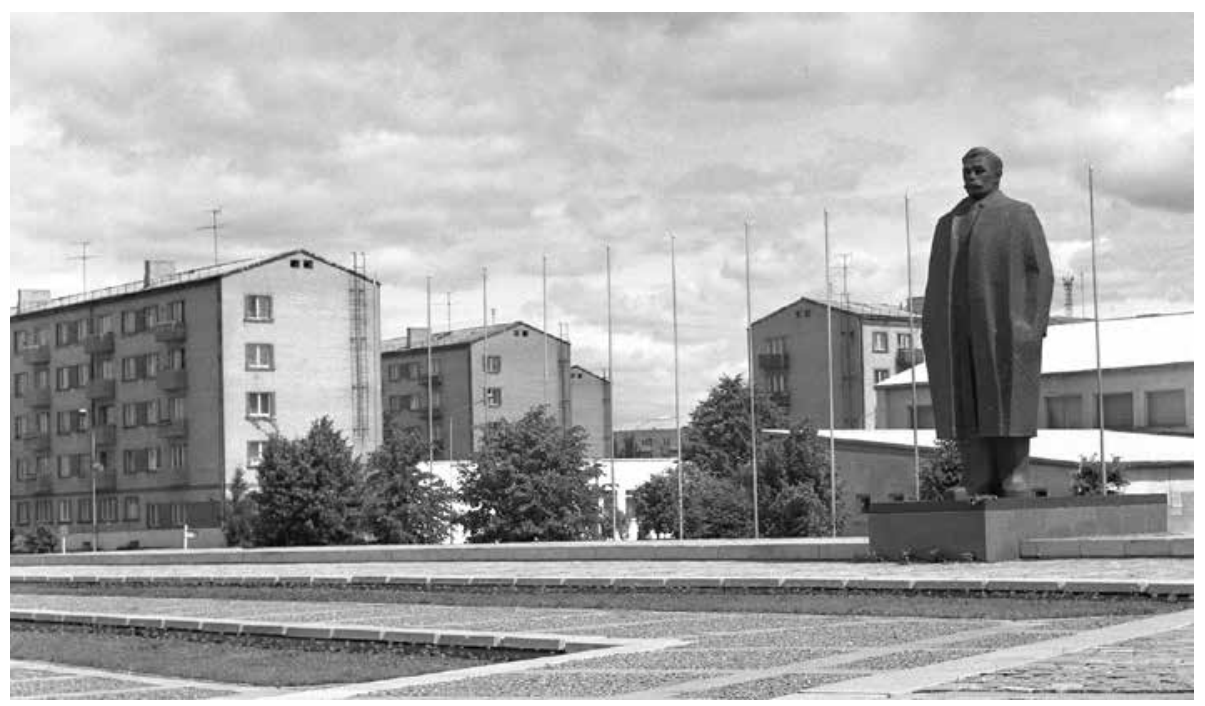

Figure 5: M. Lukaža, I. Lukažs, Z. K̦ēde. Monument to Pēteris Stučka in Aizkraukle. 1978-1991. Bronze, $h=7 \mathrm{~m}$ (figure), granite, $\mathrm{h}=1 \mathrm{~m}$ (pedestal). Courtesy of the National Administration of Cultural Heritage. 
The generation of young sculptors that graduated the Arts Academy in 1960s renounced the tectonic principles of their teachers in order to explore the connotative resources of dynamic atectonic constructions. Sophisticated techniques permit the misrepresentation of mechanical load / support strains. The load bearing structures of sculptures are concealed in two ways: 1) the casing of metal plates hides its supportive carcass, 2) the contact area between sculpture and its support is disproportionally small and the joints are not exposed. Since the exposed distribution of masses violates the gravity law, the viewers are expected to imagine the load as a gliding body, evoking connotations of motion, change and tensity.

Projects put out to a tender for the construction of the World War II memorial in Audrini, in 1962, reflected the artists' efforts to discover the expressivity of complex constructive structures (Figure 6). The jury selected a traditional design with clear tectonics (a scaled-up easel sculpture); a more dynamic composition provoked controversial appraisals. A jury member claimed that the project was too far modern and incomprehensible for the public, whereas an art critic praised the contrast between light architectural forms and strong figurative sculptures (Červonnaja 1962). The rejected design envisaged an irregular form column with a cantilever platform in its lower part on which a small figure of crying child was standing. The construction symbolized the remaining carcass of a masonry stove of a house burnt to ashes. The atectonic memorial indeed stands for an unsteady building having lost its constructive strength in flames. Sculptors Zenta Zvara and Valdis Albergs and architect Ivars Srautmanis proceeded with false tectonics in a World War II monument in Vietalva in 1968 (Figure 7). They drew the symbolical advantage of the load/support proportion. A tapping copper sculpture of two battling knights (sword and shield refer to the battles of Latvian tribes against Teutonic knights) is placed on two short columns which stand on a disproportionally large pedestal erected on an artificial hillock. Two metal beams serving as an immediate support to the sculptures connote the frame of what is recognized as a mythical event described in an epic poem. The gliding effect on the sky background strengthens immateriality of the image thereby justifying the presence of a mythical scene in the war memorial.

The bronze monument to writer Andrejs Upītis, rather cautiously, departs from the granite-like statics by imparting dynamics to a minor accessory: a coattail is deflected suggesting a breath of wind (Figure 8). The image of a World War II hero, Imants Sudmalis, carries more impressive signs of motion (Figure 9). The personage wears a waterproof cape fluttering in the wind, his right arm is bended and left arm is stretched back. Looking from the side the bronze cape appears as misbalancing the figure; to make sense of the artwork the viewer has to interpret this portion of bronze as an accessory cast in light material. 


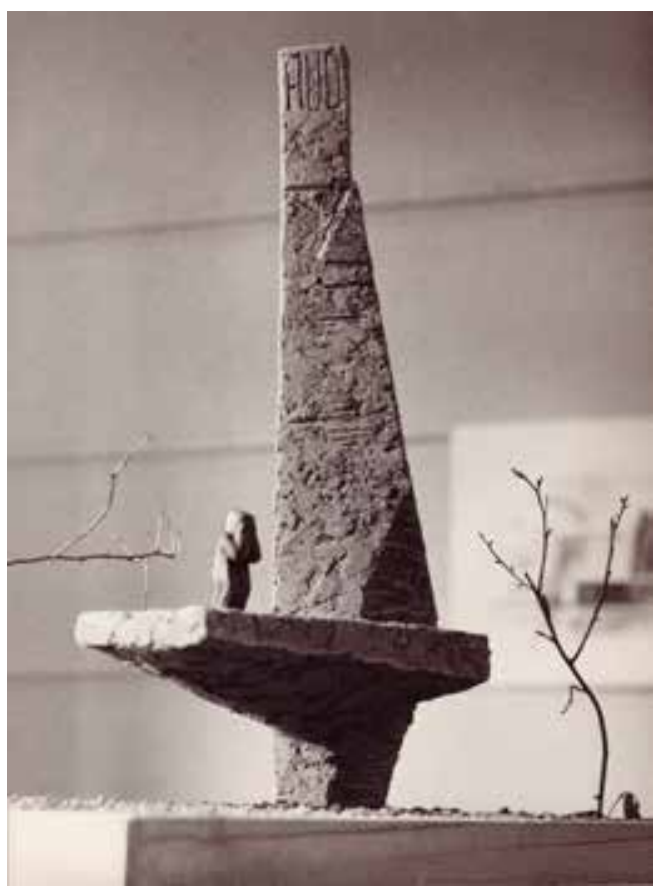

Figure 6: Z. Zvara and V. Albergs. Design of the monument to the Nazi Victims in Audrini. 1962. Courtesy of the Latvian Academy of Arts.

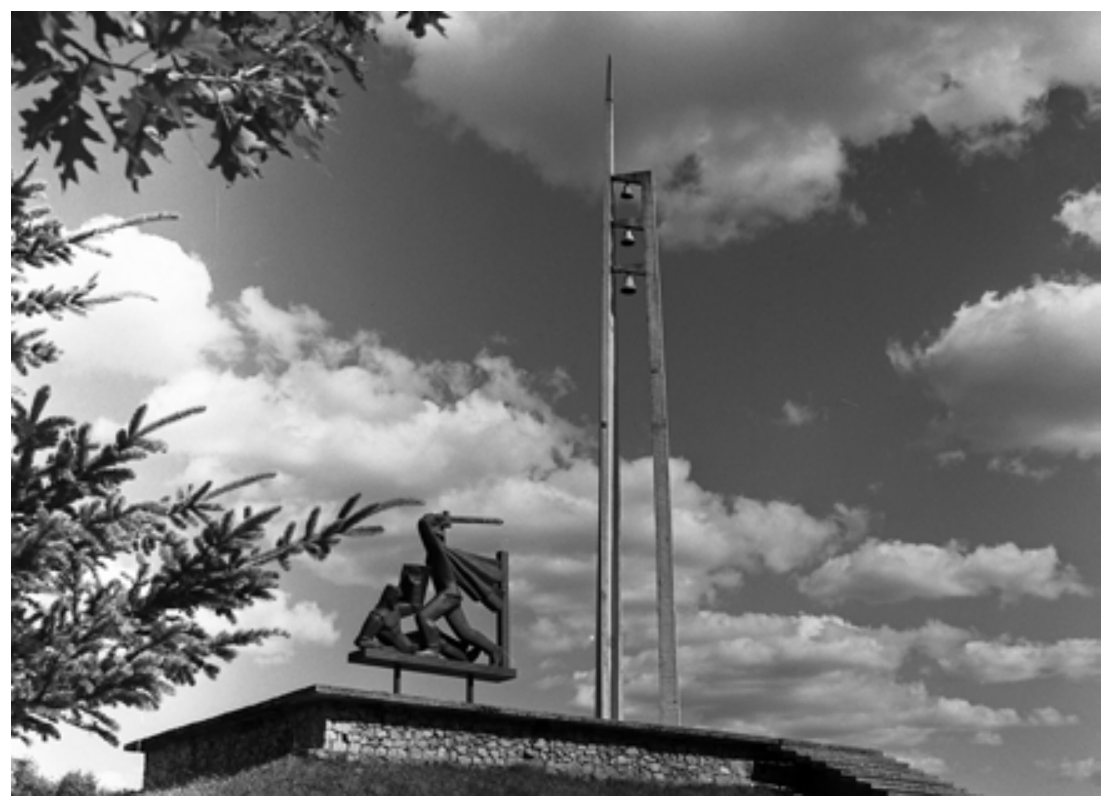

Figure 7: Z. Zvara and V. Albergs. World War II memorial in Vietalva.1968. Copper, h=3 m (figure), reinforced concrete, $h=18 \mathrm{~m}$ (obelisk). Courtesy of the National Administration of Cultural Heritage. 


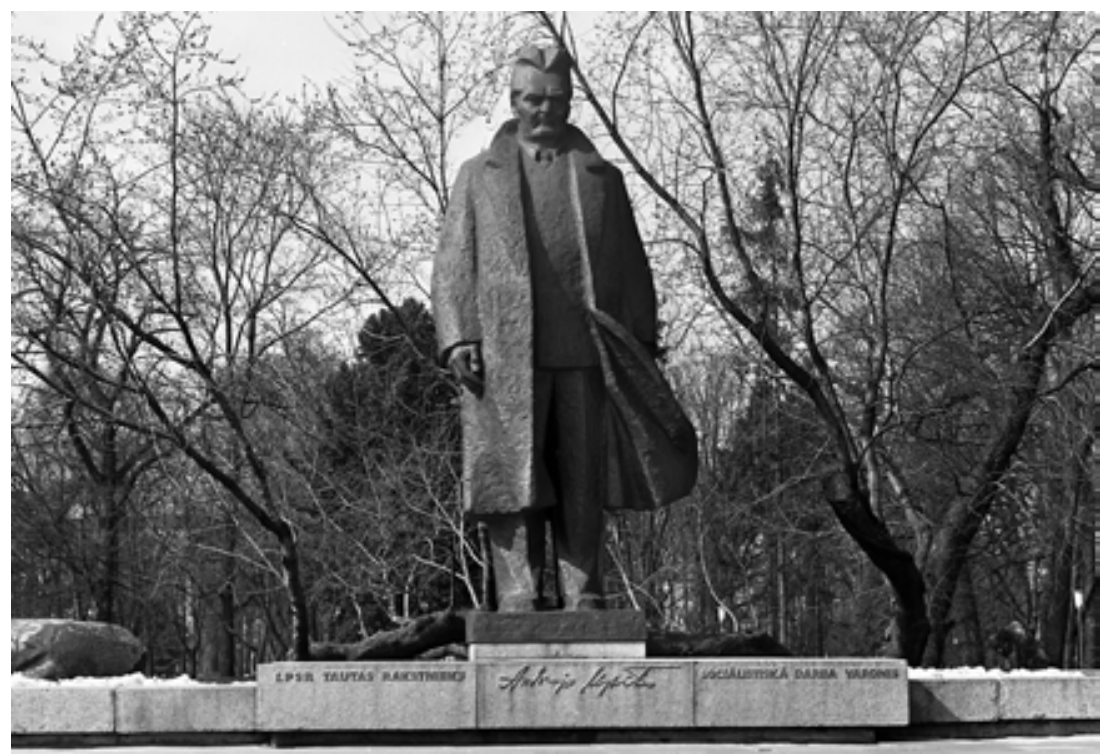

Figure 8: A. Terpilovskis. Monument to the writer A. Upīts in Riga. 1982. Bronze, h=4.5 m. Courtesy of the National Administration of Cultural Heritage.

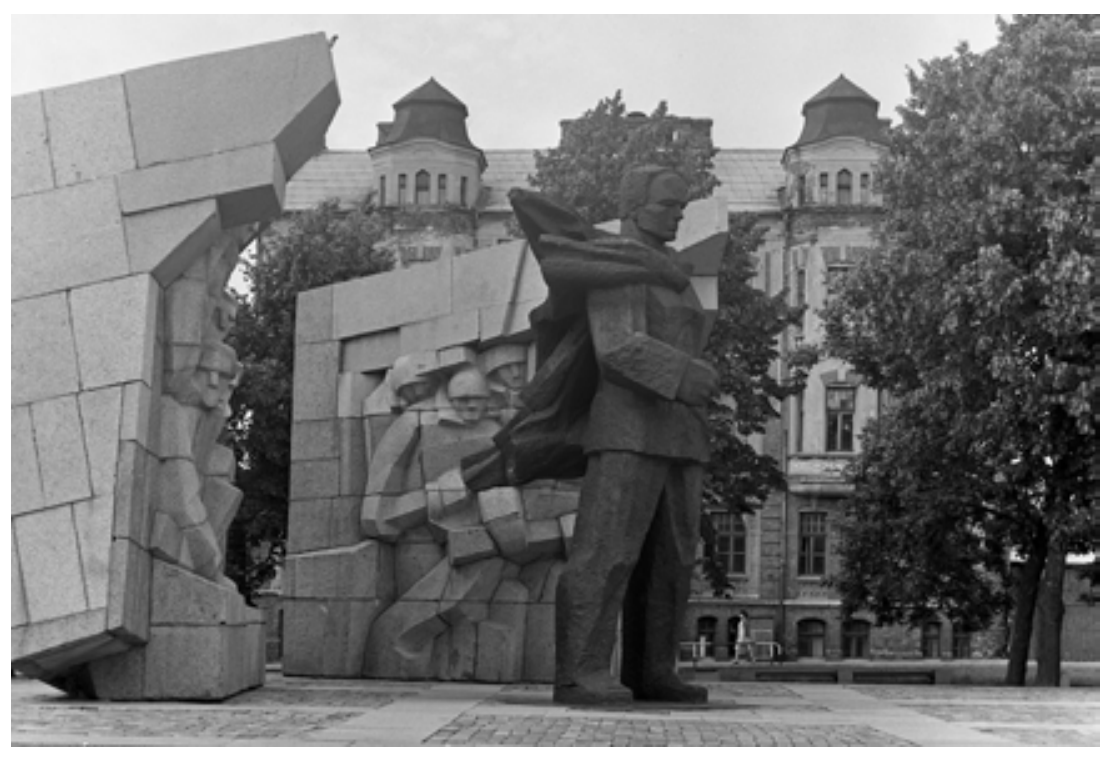

Figure 9: V. Albergs and G. Grundberga. Monument to World War II hero I. Sudmalis. Liepāja. 19781995. Bronze, $h=7 \mathrm{~m}$ (figure), concrete, $h=7.5 \mathrm{~m}$ (haut-reliefs). Courtesy of the National Administration of Cultural Heritage.

Casing on a carcass permits a more complex manipulation with masses. Rasa Kalniña-Grīnberga designed a monument to World War II soldiers (1984) in Jelgava (Figure 10). The image represents three heads of warriors emerging from the flames. The sculpture was molded in 
steel reinforced plaster and sheathed with copper plates. Due to negligence the plaster had not been removed from the sculpture; the reinforcement bars corroded in the course of time undermining the stability of construction. The municipality disposed no resources for the restoration, to escape the imminent collapse the monument had to be dismantled in 1997.

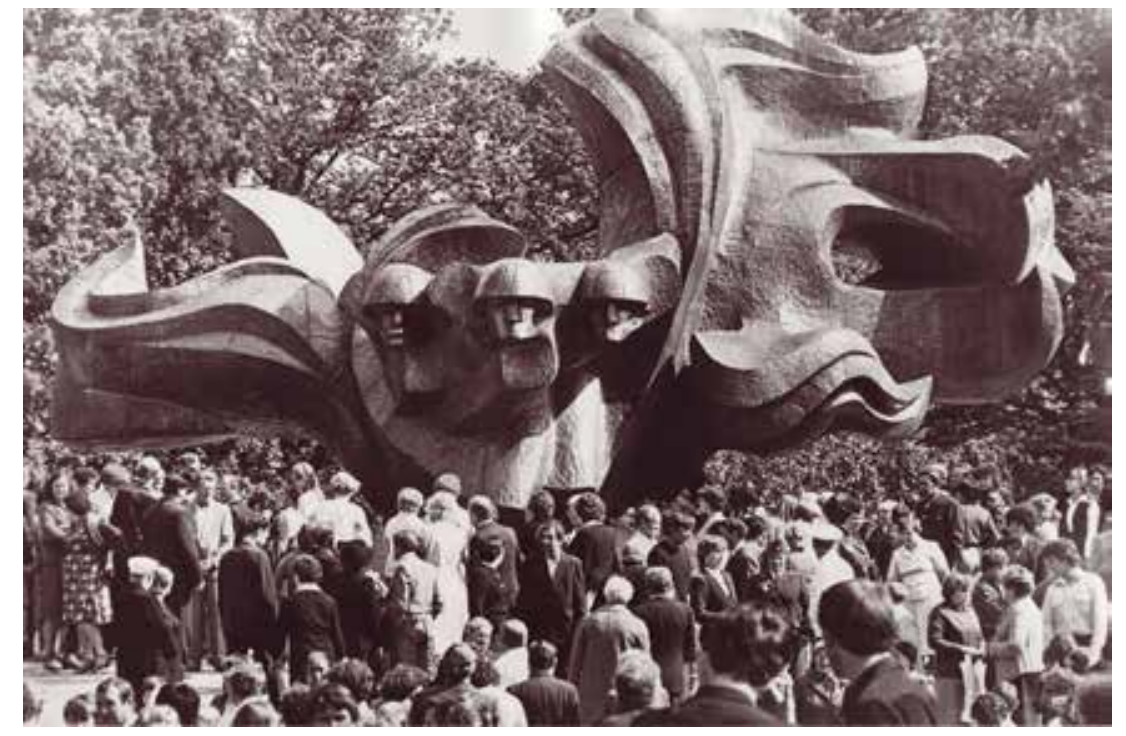

Figure 10: R. Kalnina-Grīnberga. World War II memorial in Jelgava.1984-1997. Copper and granite. Courtesy of the National Administration of Cultural Heritage.

Cantilever technology is another means imparting dynamics to monuments. Muse of Revolution is a bronze female figure supported as a cantilever on a column (Figure 11). The effect of a gliding body is strengthened by the dynamic positioning of hands. World War II monument in Valmiera consists of two travertine faced walls whose bases are narrower than upper parts (Figure 12). The walls are united by horizontally attached cantilevers - bronze figures of soldiers. One of them is firmly attached to the wall - a fallen man, the second looks rising on his feet.

It is not the material that dictates the construction technique. Some artists working in bronze and copper treated mass just like their colleagues did with granite. Figures have lowered hands, closed legs-columns stand on a low plinth - the center of mass secures a firm balance. Pauls Jaunzems on his turn manages to impart dynamics to bulky stone compositions. As the joints between stones are not visible, the whole aggregate leaves an impression of precariously balanced masses. The visually perceived meaning is grasped by the titles: The Balance, The Sign and The Sky (Figure 13). These compositions are made of two ellipsoid polished stones placed on each other. The stones are joined in the point of contact of two elliptic surfaces without any evidence of metal reinforcement. The viewer expects a quick sliding of the 
upper body due to its mass and low friction of polished surfaces however a precarious balance is enduring. A metaphorical interpretation can reconcile the viewer with physical impossibility of persisting mechanical tension.

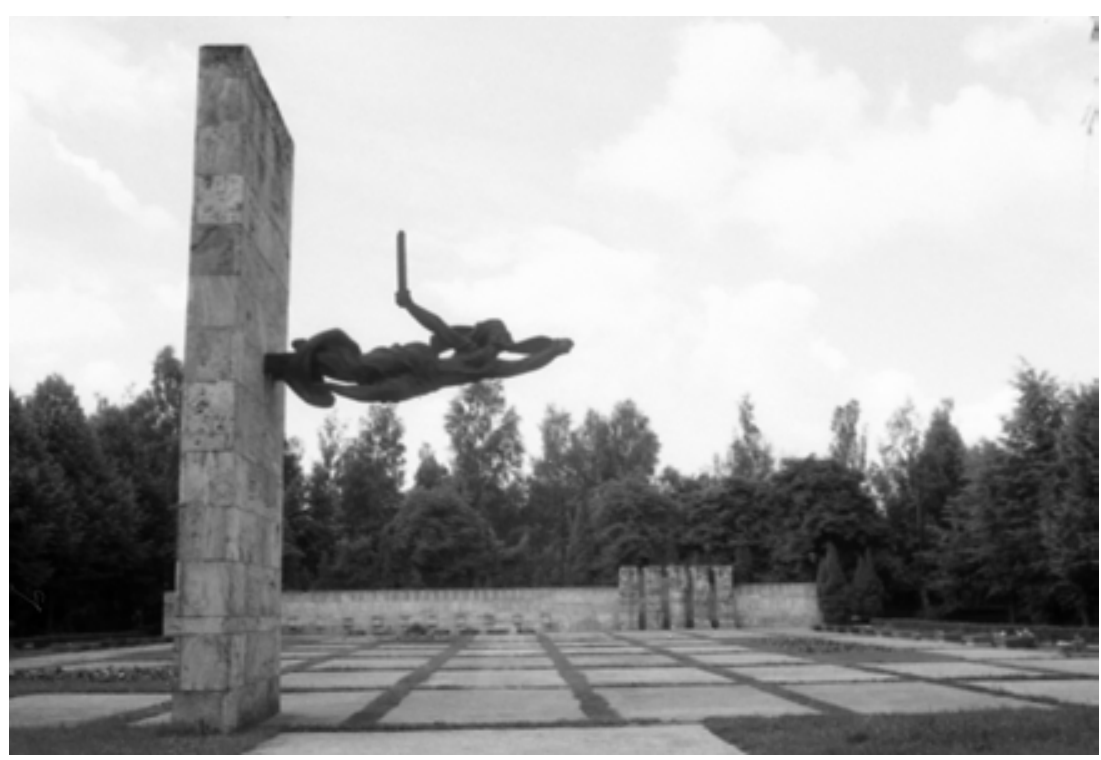

Figure 11: A. Gulbis. „The Muse of Revolution” in Riga. 1971. Copper (figure), travertine (wall). Courtesy of the National Administration of Cultural Heritage.

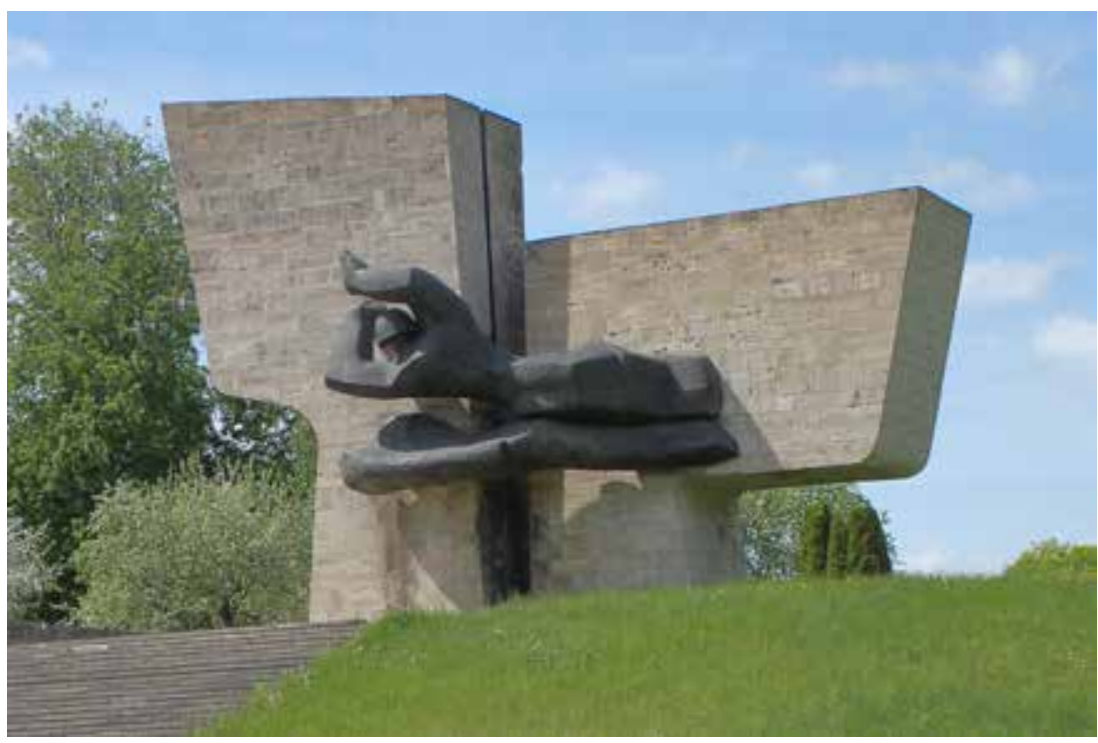

Figure 12: Z. Fernava and Yu. Tishchenko. World War II memorial in Valmiera. 1985. Bronze (figure), travertine (wall). Photo by Sergei Kruk. 


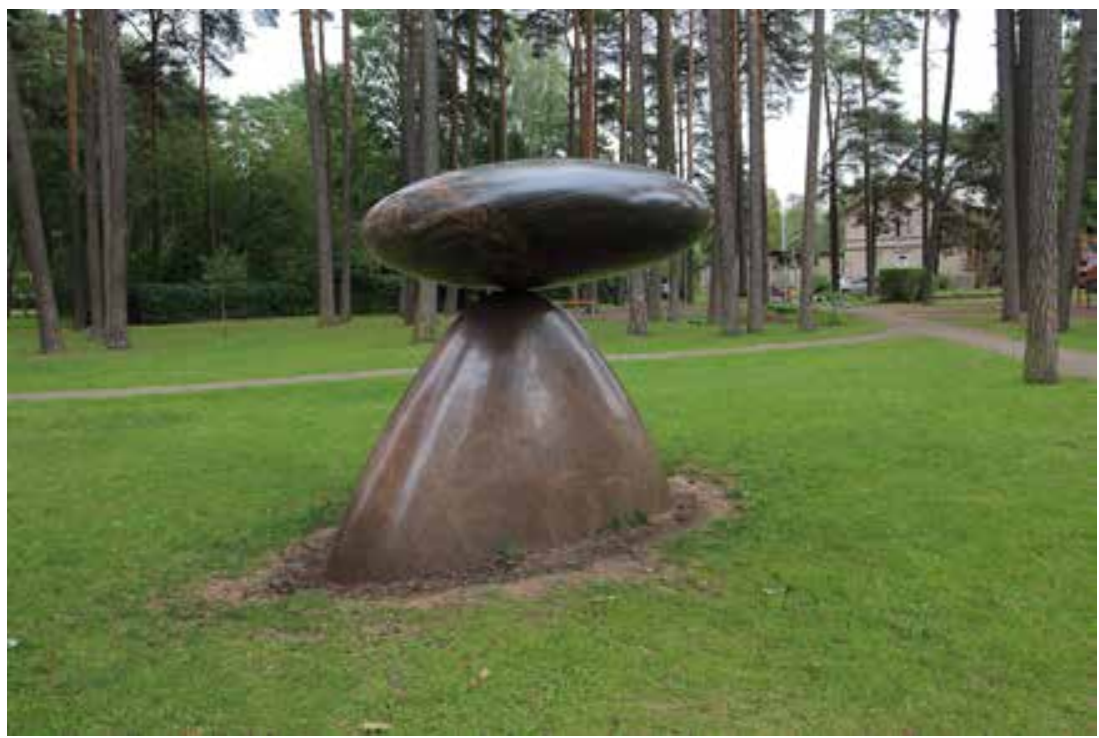

Figure 13: P. Jaunzems. Decorative sculpture „The Sky” in Jūrmala. 1990. Granite. Photo by Sergei Kruk.

Concerns with the mass induced connotations were behind the choice of material for the monument of cosmonaut Yuri Gagarin (Figure 14). The initial design envisaged a granite bust, but underway the authors opted for the bronze. The spherical bust represents the space-suit helmet and also it resembles the spaceship Vostok descent vehicle. A narrow contact area between the sphere and its pedestal connotes the readiness to lift off, the upward direction is indicated by two clusters of eight meters high duralumin poles arranged behind the sphere. A round plinth connoting the launch pad strengthens the impressions of final countdown and vertical dynamics. In this isotopy a hollow metal artefact has more chances to get off the ground than a heavy granite object envisaged initially.

In 2008, Pauls Jaunzems achieved the opposite effect contrasting body's shape to mass. A composition Morning consists of 15 bright polished red granite balls of 65 centimeters diameter regularly arranged in the museum's hall. The spherical form and polished surface connote smooth movement whereas the granite mass hampers this interpretation. The balls are placed amid the Tuscan order columns which magnify the effect of stark stability. Seeking to visualize the mass the installation of exposition was turned into a spectacular athletic performance. Weightlifting athletes carrying the granite balls into the museum reminded the public that the mass can convey meaning too. 


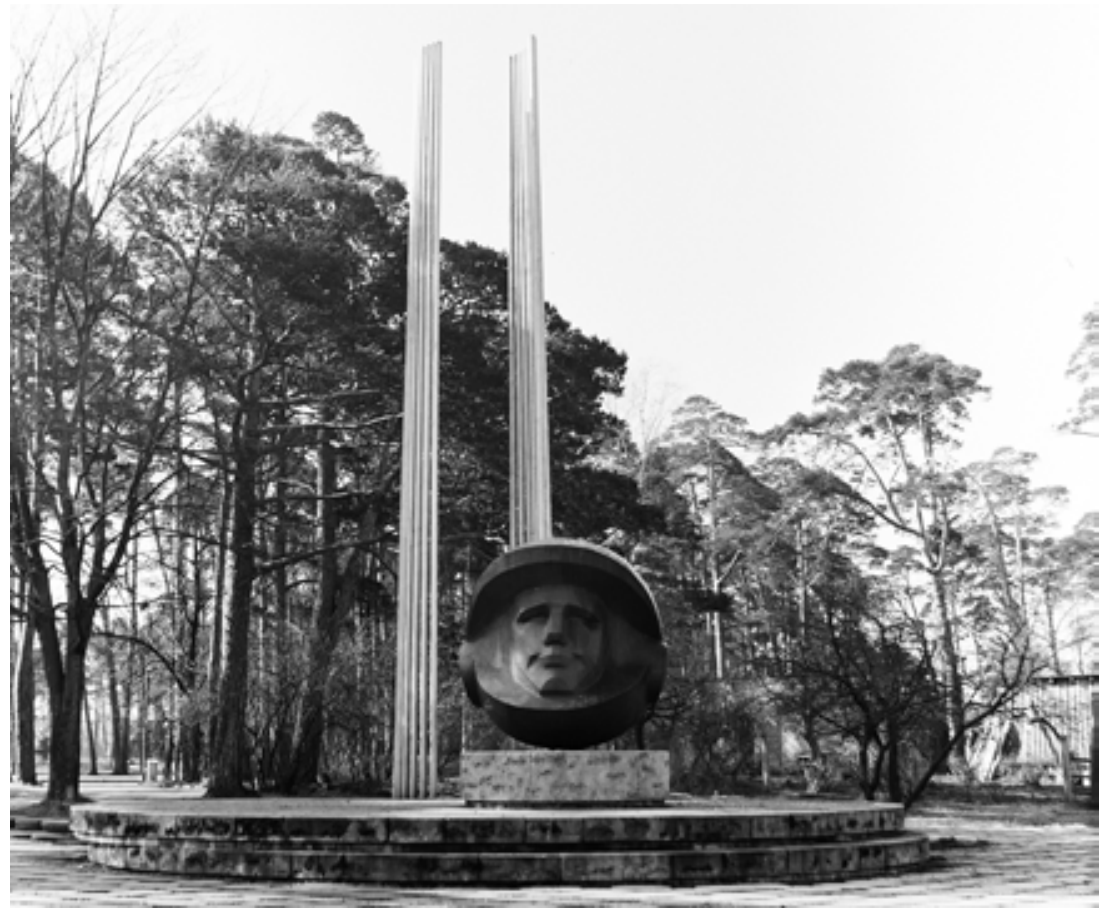

Figure 14: O. Silinšs. Yuri Gagarin monument in Ventspils. 1972-1992. Bronze, dia=3 m (bust), duralu$\min , \mathrm{h}=8 \mathrm{~m}$ (poles). Courtesy of the National Administration of Cultural Heritage.

Ambiguous sculptural bodies engage mass in consideration explicitly. Sculptor Aigars Bikše exposes the mass of his artwork drawing the viewer's attention to its material structure. The content of the visual message - the figurative image - is relegated to the second plan because the author wants to deconstruct the meaning of the word monument. In 2009, a sculptural image of Lenin was placed in Riga right where the monument was standing in 1950-1991 (Figures 15-17). The image was made of soft plastic material which was inflated and flattened periodically. Light as the air the monument can be removed, stored and re-erected with ease. The sculpture turns the famous expression of Karl Marx against the Soviet variant of Marxism: the Lenin monument that once was solid melts into air. Ironically such a kind of monuments suits well the giddy turnabouts of the East European countries with their abrupt changes of political regimes. Inflatable sculpture is a handy tool for the symbolic expression of loyalty. Five years later Bikše carved sculptures representing German, Polish, Swedish and Russian rule in Riga since the $13^{\text {th }}$ century. Fixed on hoisting devices inside a black wooden box these sculptures emerged above the box-pedestal one after another. Bikše's urban installations are monuments because they commemorate a prominent person or a historical event by virtue of iconic likeness; but the material structure deprives them the status of monument because they are not durable and can be dismantled effortlessly. 

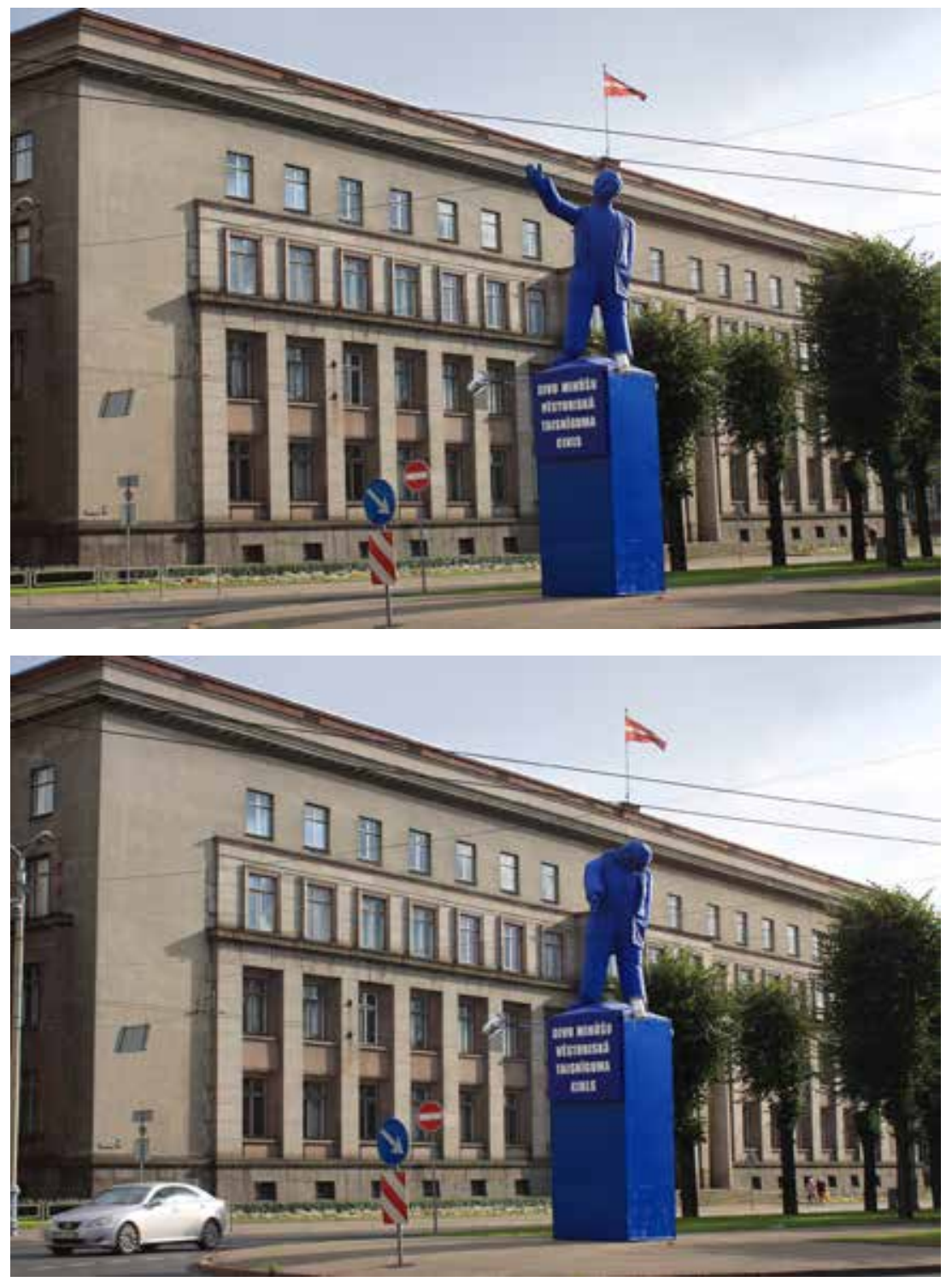

Figures 15 and 16: A. Bikše. A parody on Lenin monument in Riga. 2009. Photo by Sergei Kruk.

The third example is an installation in support of the Contemporary Art Museum in Riga whose project has been delayed for several years. Fourteen plastic sculptures of snails were scattered on the urban streets and parks in May 2014. Wooden planks placed behind the snails carried a text: Stand up here and push! Help us to the Contemporary Art Museum project to get started. Take a picture of yourself pushing. The artists envisaged that a direct experience of mass would motivate the passers-by to reflect on their verbal message and to create meaning of this public intervention in government cultural policy. 


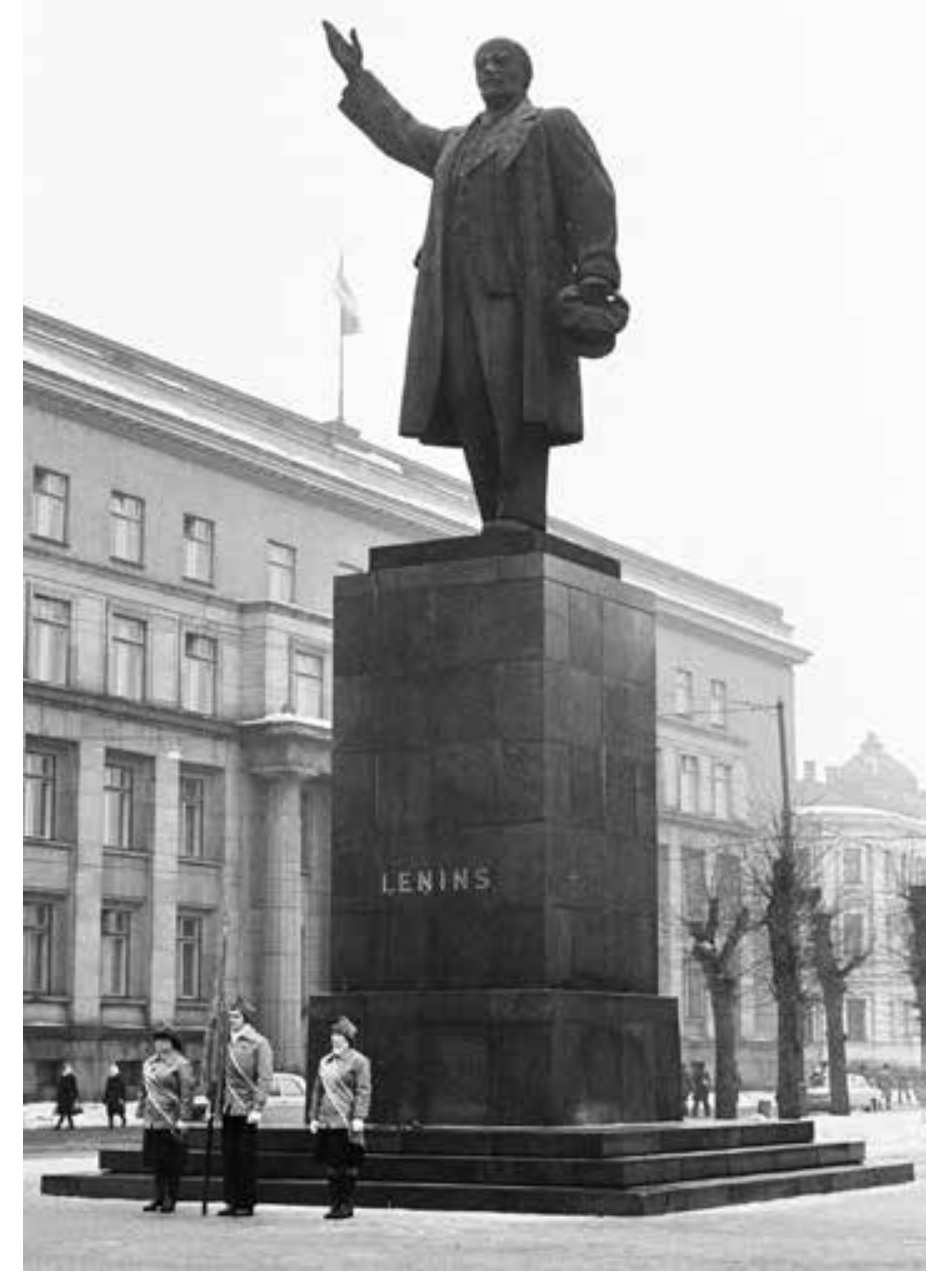

Figure 17: V. Ingal and V. Bogoliubov. Lenin monument in Riga. 1950-1991. Bronze, h=6 m (figure), granite, $h=6.25 \mathrm{~m}$ (pedestal). Photo by Boris Kolesnikov. Courtesy of the author.

Explicitly this last case respects Herder's idea that perception of objects involves the sense of touch. Nevertheless, there are many objects which we cannot touch even if we are allowed to. How can we perceive the mass as a plastic sign observing monuments visually?

\section{Perceiving and interpreting the mass}

The load/support strains increase a connotative potential of sculptural artwork. But how can we perceive the physical characteristics of its constructive blocks when we cannot explore them 
haptically i.e. by touching and handling them? I have not found a direct answer to this question in psychology of visual perception. Nevertheless, the progress of this discipline suggests some encouraging findings for semiotics of sculpture. Neuroscientists maintain that human vision is not a unitary psychological ability; seeing is not a single kind of action (Jacob and Jeannerod 2003). A distinction between inferential and ecological theories of perception (Lappin 2013) is helpful explaining the difference of semiotic analysis of 2D and 3D phenomena. Inferential theories are preoccupied with elementary attributes directly related to elementary coding processes of a single sensory modality akin to Peircean Firstness. The belief that the information about other qualities of a visual object is being merely inferred from the sensory data in the course of cognitive process accords priority to directly perceivable plastic signs like forms, lines and colors. The brain creates a coherent 3D organization of perceived scenes, characteristics and meanings from a limited sensory evidence about objects and events. Empirical and theoretical evidence however exposes the inadequacy of this conception. Our visual perception cannot be reduced to the study of the sensory input alone (Gordon 2004; Grossberg 2004; Mausfeld 2010; Reisberg 2010). Visual exploration of objects is influenced by our ability to act on the environment. Relations between perception and behavior are examined in the ecological theory. 'Efficient visual exploration depends on deciding how to coordinate visual exploration amidst the informational and motor demands of other ongoing actions [...]. Nearly every study of naturalistic visual exploration shows the importance of task, self, and whole-body exploration' (Franchak 2019: 219). Inferential theories study vision as looking at rather than as looking around. James Gibson, the founder of the ecological approach in psychology of perception, distinguishes between the visual field and the visual world. The former 'consists of a patchwork of colors something like a picture' whereas the latter 'consists of familiar surfaces and objects one behind another' (Gibson 2015 : 196). Looking around is an active process involving not only eyes but movement of the head and body. We become aware of the world actively exploring the environment over time. Not only the appearance of an object is interesting for us, but we might want also to know about its functions. The entire process of perception depends on the perceiver's knowledge and purposes in the contact with reality, the ecological theory contends (Franchak 2019; Lappin 2013). Properties of objects which are not expressed by purely visual attributes can be grasped visually by the viewer. 'This capacity is part of our more general perceptual capacity for making causal assignments and for embedding all of our experiences into various kinds of internal causal analyses' (Mausfeld 2010: 159). The perceiver goes beyond the information given in organizing and interpreting the visual input. Two different paths of visual stimuli processing revealed by neuroscience - ventral and dorsal - are comparable to looking at and looking around modalities. A teacup, for example, can arouse a visual percept and also it can be the target of reaching and grasping. 'The semantic processing of a visual stimulus yields a visual percept, whereas basic pragmatic processing yields a visuomotor representation of a target for action' (Jacob and Jeannerod 2003: 247)

Iconic representations of faces, bodies and objects, geometrical forms, colors, spatial dis- 
tribution of volumes - these visually perceived features might suffice to understand the artwork. Sculptors choose construction materials and techniques of blocks assembly in order to draw viewer's attention to the physical qualities intrinsic to solid body. As viewers we have enough time to explore the outdoor sculpture which is a part of our everyday life. Since it is present to our attention constantly, we can observe it from different angles, in different weather conditions, being in different emotional and cognitive states ourselves. Also, we act towards the sculptures: we pass them by daily, at the foot of monument we make a date, lay flowers and take photos. Practical experience of the surrounding world helps us to tell materials one from another. In any case, the sculptor does not set a riddle to solve using the formula $m=V \rho$, where the density $\rho$ most often cannot be estimated visually. Artists may imitate the surfaces and disguise the solid body's mass behind a coating made of less dense material. Mass as a plastic sign should not be confused with the physical mass of the object. Manipulating with the load/support distribution the sculptor makes the viewer to think about the mass which sparks off new meanings related to gravity and inertia forces. Physical mass tells us about the technology of solid image production, mass as a plastic sign engages us in semiosis.

\section{Conclusion}

There is a long tradition of analyzing sculpture like planar images. The notion of plastic signs as minimal units composing complex iconic signs and carrying meaning specific to their materiality allows treating mass as a semiotic resource peculiar to sculpture and 3D objects in general. The minimal construction units of sculptures are solid bodies, casings and gridshells possessing the mass. Assembling an artwork, the sculptor distributes the masses of construction units in space. Being the measure of gravity and inertia, the exposed mass evokes connotations corresponding to these physical qualities: motion, standstill, slowness, speed, change, stability. Even if touching and handling sculptures often is not possible we can infer the object's mass from the visual input, psychology of perception suggests. The mass qualifies as a plastic sign sui generis because it is a signifier which we can perceive visually and it is related to a range of signifieds which we can actualize interpreting the context of artistic message.

\section{NOTES}

1 Central State Archive of Literature and Art in St. Petersburg, TsGALI SPb. F. 283. Op.2. D. 1105. L. 29.

2 TsGALI SPb. F. 283. Op. 2. D. 3964. L. 9, 14-19.

3 TsGALI SPb. F. 78. Op. 1. D. 363. L. 13. 
4 Estonian law erected bureaucratic barriers to large-scale art exceeding 15,000 rubles cost (Kruk 2016). The easel sculpture tradition was more significant for Estonian monument-makers. Lithuanian artists followed the path of traditional and Catholic baroque wooden sculpture.

\section{REFERENCES}

Alcan, Denis 1981. Sculpter: notes à partir de Brancusi. Communications 34: 159-166.

Arnheim, Rudolf 1974. Art and visual perception: A psychology of the creative eye. Berkeley and Los Angeles: University of California Press.

Artyukhovich, D. 2011. Stroitelstvo: Entsiklopedicheskii slovar [Construction: Encylopedic dictionary]. Stavropol: Paragraf.

Azizyan, Irina 2010. Inobytie art-deco v otechestvennoi arkhitekture [The otherness of art-deco in the Soviet architecture]. In: Yulia Kosenkova (ed.). Arkhitektura stalinskoi epokhi. Moscow: URSS, 50-63.

Batorevich, Natalya and Tatyana Kozhitseva 2001. Arkhitekturnyi slovar [Dictionary of architecture]. St. Petersburg: Stroiizdat.

Bolshaia Sovetskaia Entsiklopedia [Great Soviet encyclopedia] 1926-1947. First edition. 65 volumes. Moscow: Sovetskaia Entsiklopedia.

Bolshaia Sovetskaia Entsiklopedia [Great Soviet encyclopedia] 1949-1958. Second edition. 50 volumes. Moscow: Bolshaia Sovetskaia Entsiklopedia.

Bolshaia Sovetskaia Entsiklopedia [Great Soviet encyclopedia] 1969-1978. Third edition. 30 volumes. Moscow: Sovetskaia Entsiklopedia.

Bötticher, Karl 1852. Die Tektonik der Hellenen. Potsdam: Ferdinand Niegel.

Calabrese, Omar 2006. Come si legge un'opera d'arte. S.L.: Mondadori Università.

Chateau, Dominique 2010. Matière et signe: la plasticité sémiotique. In: Michel Costantini (ed.). La sémiotique visuelle: nouveaux paradigmes. Paris: L'Harmattan, 233-244.

Chubarov, Igor 2005. Slovar khudozhestvennykh terminov GAKhN [Dictionary of notions of arts]. 1923-1929. Moscow: Logos.

Cielava, Skaidrīte 1980. L̦eṇina tēls latviešu padomju tēlotājā mākslā [Lenin's image in Soviet Latvian plastic art]. Padomju Latvijas Komunists 4: 51-56.

Costantini, Michel (ed.) 2010. La sémiotique visuelle: nouveaux paradigmes. Paris: L'Harmattan. Červonnaja, Svetlana 1962. Dzīvu straumi neaizbērt! [A Living Stream!]. Literatūra un Māksla 25 August, pp.3-4.

Danesi, Marcel 2004. Messages, signs and meanings. Toronto: Canadian Scholars' Press.

Deeson, Eric 2007. Collins internet-linked dictionary of physics. London: Harper Collins.

Eugeni, Ruggero 2004. Analisi semiotica dell'immagine. Pittura, illustrazione, fotografia. Milan: ISU Università Cattolica. 
Franchak, John M. 2019. Looking with the head and eyes. In: Jeffrey B. Wagman and Julia J. C. Blau (ed) Perception as information detection. Reflections on Gibson's ecological approach to visual perception. London: Routledge, 205-221.

Gabrichevsky, Alexander 1923. Prostranstvo i massa v arkhitekture [Space and mass in architecture]. Zhurnal Rossiiskoi akademii khudozhestvennykh nauk 1: 292-390.

Gibson, James J. [1979] 2015. The ecological approach to visual perception. New York and London: Psychology Press.

Ginzburg, Moisei 1927. Konstruktivizm kak metod laboratornoi i pedagogicheskoi raboty [Constructivism as a method of an experimental and pedagogical activity]. Sovremennaya arhitektura 6: 160-166.

Gordon, Ian E. 2004. Theories of visual perception. Hove and New York: Psychology Press.

Greimas, Algirdas Julien 1984. Sémiotique figurative et sémiotique plastique. Actes sémiotiques - Documents 60.

Grossberg, Stephen 2004. Neural models of seeing and thinking. In: Arturo Carsetti (ed) Seeing, thinking and knowing. New York, Boston, Dordrecht: Kluwer Academic Publishers, 29-54.

Groupe $\mu$ 1979. Iconique et plastique. Rhétoriques, sémiotiques. Revue d'Esthétique 1/2: 173192.

Groupe $\mu$ 1992. Traité du signe visuel. Paris: Seuil.

Herder, Johann Gottfried [1778]2005. Sculpture. Some observations on shape and form from Pygmalion's creative dream. Edited and translated by Jason Gaiger. Chicago and London: The University of Chicago Press.

Hildebrand, Adolf [1893]1914. Problema formy $v$ izobrazitelnom iskusstve [Das Problem der Form in der bildenden Kunst]. Moscow: Musaget.

Ikonnikov, Andrey 1986. Funktsiya, forma, obraz $v$ arkhitekture [Function, form and image in architecture]. Moscow: Stroiizdat.

Ivanova, Galina and Alexander Stepanov 2007. Tektonika kak vyrazhenie struktury obyemno-prostranstvennykh form [Tectonics as an expression of spatial forms]. In: Alexander Stepanov, Vladimir Malgin, Galina Ivanova et al. (eds) Obyemno-prostranstvennaya kompozitsiya. Moscow: Arkhitektura-S, 37-51.

Jacob, Pierre and Marc Jeannerod 2003. Ways of seeing. The scope and limits of visual cognition. Oxford: Oxford University Press.

Kazus', Igor 2010. Otechestvennye konkursy 1920-1930 godov: indikatsiia stilia [Public competitions in 1920-1930: An indication of style]. In: Yulia Kosenkova (ed) Arkhitektura stalinskoi epokhi. Moscow: URSS, 80-89.

Khan-Magomedov, Selim 2001. Arkhitektura sovetskogo avangarda. Tom 2. Sotsialnye problemy [Architecture of the Soviet vanguard. Vol. 2. Social Problems]. Moscow: Stroiizdat.

Klinkenberg, Jean-Marie 1996. Traité du signe visuel. Pour une rhétorique de l'image. Paris: Seuil. 
Klinkenberg, Jean-Marie 2010. La sémiotique visuelle: nouveaux paradigmes. In Michel Costantini (ed) La sémiotique visuelle: nouveaux paradigmes. Paris: L'Harmattan, 6-8.

Koed, Erik 2005. Sculpture and the sculptural. The Journal of Aesthetics and Art Criticism 63 (2): 147-154.

Kress, Gunther and Theo van Leeuwen 2006. Reading images. The grammar of visual design. London: Routledge.

Kruk, Sergei 2010. Profit rather than politics: the production of Lenin monuments in Soviet Latvia. Social Semiotics 20 (3): 247-76.

Kruk, Sergei 2016. Kulturnaya politika sovetskikh pribaltiiskikh respublik na primere stroitelstva pamiatnikov Leninu [Culture policy of Soviet Baltic Republics: The case of Lenin monuments]. In: Maksim Vilkov and Vladimir Simindei (comp.) Pribaltiiskie issledovaniia v Rossii, 2015. Moscow: RGASPI, 147-168.

Lancioni, Tarcisio 2012. II senso e la forma. Semiotica e teoria dell'immagine. Firenze, Lucca: La casa Usher.

Langer, Susanne K. 1953. Feeling and form. New York: Charles Scribner's Sons.

Lappin, Joseph 2013. Inferential and ecological theories of visual perception. In: Liliana Albertazzi (ed) Handbook of experimental phenomenology: Visual perception of shape, space and appearance. Oxford: John Wiley and Sons, 39-70.

Lunacharski, Anatoly 1934. Rech' o proletarskoi arkhitekture [A lecture on proletarian architecture]. Arkhitektura SSSR 8: 4-6.

Mallgrave, Harry Francis (ed) 2006. Architectural theory. Volume I: An anthology from Vitruvius to 1870. Oxford: Blackwell.

Marsciani, Francesco 1999. Del corpo-massa. In Lucia Corrain and Pierluigi Basso (eds) Eloquio del senso. Dialoghi semiotici per Paolo Fabbri. Genova: Costa \& Nolan.

Martin, F. David 1978. On perceiving paintings and sculpture. Leonardo 11 (4): 287-292.

Mausfeld, Rainer 2010. The perception of material qualities and the internal semantics of the perceptual system. In: Liliana Albertazzi, Gert J. van Tonder and Dhanraj Vishwanath (eds) Perception beyond inference. Cambridge, Mass.: The MIT Press, 159-199.

Nekrasov, Alexey 1934. Problema realizma v arkhitekture [The problem of realism in architecture]. Arkhitektura SSSR 1: 54-59.

Nekrasov, Alexey [1945-1946] 1994 Teoriya arkhitektury [A theory of architecture]. Moscow: Stroiizdat.

Nöth, Winfried 1990. Handbook of semiotics. Bloomington, IN: Indiana University Press.

O'Toole, Michael 1994. The language of displayed art. London: Routledge.

Pluzhnikov, Vladimir 2011. Terminy rossiiskogo arkhitekturnogo naslediya: Arkhitekturnyi slovar [Terminology of the Russian architectural heritage. Dictionary of architecture]. Moscow: Iskusstvo-XXI vek. 
Prokhorov, Alexander 1998. Fizika. Bolshoi entsiklopedicheskii slovar [Physics. Great encyclopedic dictionary]. Moscow: Bolshaya Rossiiskaia Entsiklopedia.

Read, Herbert 1956. The art of sculpture. London: Faber and Faber.

Reisberg, Daniel 2010. Cognition: exploring the science of the mind. New York: W. W. Norton \& Company.

Revzin, Grigory 2002. Ocherki po filosofii arkhitekturnoi formy [Essays on philosophy of architectural form]. Moscow: OGI.

Rogers, Leonard Robert 1962. Sculptural thinking. The British Journal of Aesthetics 2 (4): 291 300.

Savage, Kirk 2010. The obsolescence of sculpture. American Art 24 (1): 9-14.

Semper, Gottfried [1851]1989. The four elements of architecture and other writings. Trans. H. F. Mallgrave and W. Herrmann. Cambridge.

Serres, Michel [1987]2014. Statues. Paris: Flammarion.

Sotnikov, Boris 2009. Obyemno-prostranstvennaia kompozitsiia [Volumetric and spatial composition]. Ulyanovsk: UGTU.

Soviet stroitelstva po sooruzheniyu Dvortsa sovietov. 1932. Ob organizatsii rabot po okonchatelnomu sostavleniyu proekta Dvortsa sovietov SSSR v Moskve. Postanovlenie Sovieta stroitelstva Dvortsa Sovietov pri Prezidiume TsIK SSSR [On the final project of the palace of Soviets in Moscow]. Stroitelstvo Moskvy 3: 15-16.

Tits, Alexey 1976. Tektonicheskaia organizatsia obyemno-prostranstvennoi struktury [Tectonic assembly of volumetric and spatial structure]. In: Alexey Tits, Yury Bozhko, Galina Ivanova, Natalya Kireieva et al. (comp.) Osnovy arkhitekturnoi kompozitsii i proektirovaniya. Kiev: Vyshcha shkola, 90-122.

Tits, Alexey and Elena Vorobyova 1986. Plasticheskii iazyk arkhitektury [Plastic language of architecture]. Moscow: Stroiizdat.

Vance, Robert D. 1995. Sculpture. British Journal of Aesthetics 35 (3): 217-226.

Vlasov, Viktor 2004. Arkhitektura: slovar terminov [Architecture: Dictionary of terms]. 2nd edition. Moscow: Drofa.

Volli, Ugo 2008. Manuale di semiotica. Rome: Editori Laterza.

Yusupov, Eduard 1994. Slovar terminov arkhitektury [Dictionary of architectural terms]. St.Peterburg: Leningradskaia galereia.

Sergei Kruk is Professor of Communication at Riga Stradins University, Latvia.

Email: sergei.kruk@gmail.com 